\title{
Characterization of Pasteurella multocida isolates recovered from the oral flora of cats
}

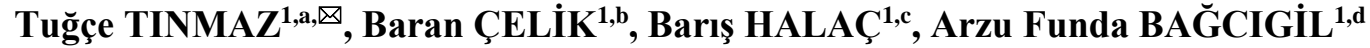 \\ ${ }^{1}$ İstanbul University - Cerrahpaşa, Faculty of Veterinary Medicine, Department of Microbiology, İstanbul, Turkey.

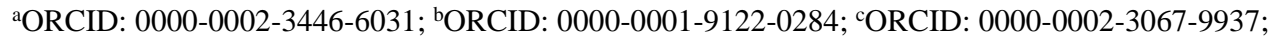 \\ ${ }^{\mathrm{d} O R C I D:}$ 0000-0002-8838-7291. \\ Corresponding author: tugcetinmaz@yahoo.com \\ Received date: 29.12.2019 - Accepted date: 12.06.2020
}

\begin{abstract}
In this study, it was aimed to investigate the presence of Pasteurella multocida in the swab samples taken from the oral cavity of cats, and to determine the capsular type and antimicrobial susceptibility of the isolates. For this purpose, swab samples taken from 300 cats were inoculated onto Knight's selective enriched medium and blood agar for isolation of $P$. multocida. Following after capsular typing of the isolates by PCR, the susceptibilities of the isolates to ceftiofur, clindamycin, erythromycin, enrofloxacin, amoxicillin+clavulanic acid, trimethoprim/ sulfamethoxazole, tetracycline, and chloramphenicol were examined by the disk diffusion method. The relationships between oral colonization and various physiological and behavioral variables were evaluated, statistically. P. multocida was isolated from $48(16 \%)$ of the samples and all strains were typed as capsular type A. While all of the isolates were resistant to clindamycin and susceptible to enrofloxacin, 8,33\% tetracycline resistance was also remarkable. Multiple antibiotic resistance (MDR) was detected in $27 \%$ of the isolates. The colonization of $P$. multocida was found to be statistically significant in cats under the age of 1 and in cats living outdoors. The importance of antibiotic resistance observed in bacteria with a zoonotic character such as $P$. multocida should not be ignored since it poses a threat to public health. It was concluded that, in this study determination of tetracycline resistance, which has started to be reported in feline Pasterurella multocida isolates in recent years, and detection of multiple antibiotic resistance in $27 \%$ of isolates, was extremely important for public health.
\end{abstract}

Keywords: Antimicrobial susceptibility, capsular typing, cat, oral swab, Pasteurella multocida.

\section{Kedilerin ağız florasından izole edilen Pasteurella multocida izolatlarının karakterizasyonu}

Özet: Bu çalışmada kedilerin ağız boşluğundan alınan svap örneklerinde Pasteurella multocida varlığının araştırılması, kapsül tiplerinin belirlenmesi ve antibiyotik duyarlılıklarının saptanması amaçlandı. Bu amaçla, 300 kediden oral svap örnekleri toplandı ve P. multocida izolasyonu için selektif zenginleştirilmiş Knight's besiyeri ve kanlı agara ekimleri yapıldı. İzolatların kapsül tiplendirmeleri PCR ile yapıldıktan sonra seftiofur, klindamisin, eritromisin, enrofloksasin, amoksisilin klavulonik asit, trimetoprim/sulfametokasazol, tetrasiklin, kloramfenikola karşı duyarlılıkları disk difüzyon yöntemi ile incelendi. Oral kolonizasyon ile çeşitli fizyolojik ve davranışsal değişkenler arasındaki ilişkileri istatistiksel olarak değerlendirildi. İncelenen örneklerin 48 (\%16)'inden P. multocida izole edildi ve tümü kapsüler tip A olarak belirlendi. İzolatların tamamı klindamisine dirençli ve enrofloksasine duyarlı bulunurken, \% 8,33 oranında tetrasiklin direnci de dikkat çekici olarak belirlendi. İzolatların \%27'sinde çoklu antibiyotik direnci saptandı. İstatistiksel analiz sonucu, bir yaş altı kediler ve dış ortamda yaşayan kedilerde kolonizasyon istatistiksel olarak anlamlı bulundu. P. multocida gibi zoonoz karakterdeki bakterilerde gözlenen antibiyotik direnci, halk sağlığı açısından tehdit oluşturduğundan gözardı edilmemelidir. Son yıllarda kedi $P$. multocida izolatlarında rapor edilmeye başlanan tetrasiklin direncinin bu çalışmada da saptanması ve tüm izolatlarda \%27 oranındaki çoklu antibiyotik direncinin gözlemlenmesinin, halk sağlığı açısından son derece önemli olduğu sonucuna varıldı.

Anahtar sözcükler: Antimikrobiyal duyarlılık, kapsüler tiplendirme, kedi, oral svap, Pasteurella multocida.

\section{Introduction}

Pasteurella species are usually found in the normal flora of the oral, nasopharyngeal, and upper respiratory tract in animals, and they are also opportunistic pathogens associated with endemic outbreaks. $P$. multocida is a species that can be isolated from the oral flora of cats and dogs up to $90 \%$. It also has a zoonotic character. Infection to people is usually caused by biting, scratching, licking or contact with nasal secretions $(3,8,12,17,19)$. $P$. multocida, has 5 capsular serogroups such as A, B, D, E and $\mathrm{F}$, and 16 somatic serotypes. The capsule plays the most important role in the identification of serogroup type. 
Different serotypes and serogroups tend to cause certain diseases $(5,14,33)$. Healthy cats are usually defined as the carriers of $P$. multocida. Cats living in nature spread bacteria in cat populations as a result of hunting and fighting. However, although cats are often reported as the carriers of P.multocida and the agent is mentioned to be a zoonotic, isolated from cat bites, there is no study on the prevalence of $P$. multocida in oral colonization of cats, the presence of virulence genes, and antimicrobial susceptibility profiles in Turkey.

The aim of this study was to isolate $P$. multocida from the oral flora of cats with a different clinical picture and to perform the capsular typing of isolates and to determine antimicrobial resistance profiles.

\section{Material and Methods}

Oral swab samples from 300 cats which were clinically healthy or were taken to veterinary clinics with various clinical symptoms in Istanbul between March 2017 and October 2018 were examined. This study was approved by Istanbul University Animal Experiments Local Ethics Board (Decision date: 23.02.2017). Swabs samples were collected from the oral mucosa to cover the inner cheek edge mucosa, gingiva and the top of the tongue, were transferred in Cary-Blair medium and stored at room temperature and brought to the laboratory within 5 days $(16,30)$. The data on breed, age, gender, antimicrobial treatment history, living-conditions of the sampled cats were recorded. According to these data, it was recorded that no antimicrobial agent had been used for last month in 286 of the cats, antibiotic therapy was performed for different reasons in 14 of them. The rest of the data collected from sampling population were showed in Table 1.

The swabs were streaked onto Nutrient Agar including $7 \%$ defibrinated sheep blood and onto selective medium contained defibrinated horse blood and antibiotics described by Knight et al. (18), and they were incubated for 24 hours at $37^{\circ} \mathrm{C}$ under aerobic conditions. Catalase and oxidase-positive isolates with Gram-negative coccobacillus morphology were considered as $P$. multocida suspected. The identification of the isolates and subsequently, capsular typing were performed according to the methods described previously $(32,33)$. The DNA extraction was performed using the commercial kit (Quick-DNA Fungal/Bacterial Miniprep, Zymo Research, CA, USA). Identification and capsular typing of $P$. multocida isolates were performed (32) with ready-to-use mix (MyTaq HS mix, Zymo Research, CA,USA), and amplification protocol was applied as preliminary denaturation at $95^{\circ} \mathrm{C}$ for 5 minutes, and denaturation at $95^{\circ} \mathrm{C}$ for 30 seconds, annealing at $55^{\circ} \mathrm{C}$ for 30 seconds, extension at $72^{\circ} \mathrm{C}$ for 30 seconds and final extension at $72^{\circ} \mathrm{C}$ for 5 minutes in total of 30 cycles. A field isolate obtained from Samsun 19 Mayis University, Faculty of Veterinary Medicine, Department of Microbiology, and the strains coded PM492 (Capsule type A), PM 498 (Capsule type B) obtained from Dr. Conny Turni from the University of Queensland were used as positive controls in the study.

The antimicrobial susceptibilities of the isolates were examined by the disk diffusion method according to The European Committee on Antimicrobial Susceptibility Testing [amoxicillin/clavulanic acid (20/10 $\mu \mathrm{g})$, tetracycline $(30 \mu \mathrm{g})$, trimethoprim-sulfamethoxazole $(1.25 / 23.7 \mu \mathrm{g})]$ (31), and The Clinical and Laboratory Standards Institute [ceftiofur $(30 \mu \mathrm{g})$, chloramphenicol $(30 \mu \mathrm{g})$, enrofloxacin $(5 \mu \mathrm{g})]$ (7) [clindamycin $(2 \mu \mathrm{g})$ and erythromycin $(15 \mu \mathrm{g})](27)$ criteria. Escherichia coli ATCC 25922 was used as quality control (QC) strain. The isolates which were found to be resistant to three or more antibiotic classes were defined as multidrug resistance (MDR) (20).

Table 1. Sample characteristics and statistical data: all cats' age, living conditions, gender, drug history information, respectively, and number of cats found to be positive and negative in terms of $P$. multocida by PCR.

\begin{tabular}{|c|c|c|c|c|}
\hline Variables & Total (\%) & PCR positive (\%) & PCR negative $(\%)$ & P-value \\
\hline \multicolumn{5}{|l|}{ Age (years) } \\
\hline$<1$ & $51(17)$ & $2(3.9)$ & $49(96.0)$ & 0.0045382* \\
\hline $1-6$ & $217(72)$ & $39(17.9)$ & $178(82.1)$ & 0.131188 \\
\hline$>6$ & $32(11)$ & $7(21.8)$ & $25(78.2)$ & 0.337494 \\
\hline \multicolumn{5}{|l|}{ Living condition } \\
\hline Indoor & $161(53.6)$ & $31(19.3)$ & $130(80.7)$ & 0.097945 \\
\hline Outdoor & $71(23.6)$ & $4(5.6)$ & $67(97.4)$ & 0.0031971* \\
\hline Indoor/Outdoor & $68(22.6)$ & $13(19.1)$ & $55(80.9)$ & 0.425195 \\
\hline \multicolumn{5}{|l|}{ Gender } \\
\hline Female & $167(55.6)$ & $28(16.8)$ & $139(83.2)$ & 0.684907 \\
\hline Male & $133(44.3)$ & $20(15.03)$ & $113(84.97)$ & \\
\hline \multicolumn{5}{|l|}{ Drug History } \\
\hline Not used & $286(95)$ & $47(16.4)$ & $239(83.6)$ & $0.3126667 *$ \\
\hline Used & $14(5)$ & $1(7.1)$ & $13(92.9)$ & \\
\hline
\end{tabular}

CI 95\%, Fisher's exact test was used in the analyses with * mark, Pearson's chi-square test was used in others. P<0.05 was considered statistically significant in all analyses. Significant values are shown in bold characters. 
Colonization rates (prevalence $=$ number of colonized cats/number of cats examined $\mathrm{x}$ 100) were calculated and colonization relation with demographic variables analyzed by SPSS for Windows, Version 17.0 (SPSS Inc. Chicago, USA, Released 2008). The prevalence rates (PR) and the relevant $95 \%$ confidence interval values $(95 \% \mathrm{CI})$ were calculated for the categorical variables associated with colonization for the control of infection. The relationship between oral colonization and age (below the age of 1, 1-6 years, over the age of 6), living conditions (indoor, outdoor, indoor/outdoor), gender (female/male), and antibiotic usage was investigated. The chi-square test was used for the estimation of independence of categorical variables, and Fisher's exact test was used when the expected cell value was below 5. A P-value $<0.05$ was considered statistically significant in all analyses performed.

\section{Results}

P. multocida was recovered from 48 of the samples, the isolation rate was found to be $16 \%$. All isolates were belonged to capsular type-A. It was observed that no drug was used in the last month in 47 of the cats from which $P$. multocida was isolated, and an antibiotic was used for different reasons in only one of them. It was determined that 28 of the cats were female and 20 of them were male, 31 of them lived only indoor, 4 of them lived outdoor and 13 of them lived both indoor and outdoor.

As a result of antimicrobial susceptibility tests, while all isolates were found to be resistant to clindamycin, it was determined that the other most resistance were against to trimethoprim+sulfamethoxazole (co-trimoxazole) combinations in 15 isolates and amoxicillin+clavulonic acid combinations in 14 isolates. Antibiotics with the least resistance were found as chloramphenicol (2 isolates) and tetracycline (4 isolates). All isolates were susceptible to enrofloxacin. While resistance to a single antimicrobial agent was found in $35.42 \%(n=17)$ of isolates, resistance to two antimicrobial agents was found in $37.50 \%(n=18)$ of them, resistance to three antimicrobial agents was found in $20.83 \% \quad(n=10)$ of them, and resistance to four antimicrobial agents was found in $6.25 \%(n=3)$ of them. In this case, the prevalence of multiple antibiotic resistance was found to be $27 \%$. Distribution of antimicrobial susceptibilities and antimicrobial resistance profiles of the isolates were presented in Table 2 and 3 respectively.

When gender and the presence of colonization were evaluated, the ratios between males and females were found to be $15.03 \%$ and $16.8 \%$, respectively, and the difference between them was not found to be statistically significant (Pearson's $=0.165, \mathrm{P}=0.684907$ 95\% CI: -0.061
$<0.016>0.092$ ). Similarly, colonization was not found to be statistically significant in the samples taken from the animals with (7.1\%) and without drug use (16.4\%) (Fisher's exact test $=0.857, \mathrm{P}=0.3126667,95 \%$ CI: 0.327 $>2.556>20.015$ ). Colonization rates were found to be $3.9 \%, 17.9 \%$, and $21.8 \%$ in the age groups of under age of $1,1-6$ years and over the age of 6 , respectively. The colonization rate was found to be statistically significant in animals under the age of 1 ; at value $95 \% \mathrm{CI}$ : $-0.262<-$ $0.149>-0.036, \mathrm{P}=0.0045382$ (Fisher's exact test). Similarly, when living conditions were compared, colonization was found to be statistically significant in animals living outdoor (95\% CI: $-0.263<-0.153>-0.043$ $\mathrm{P}(\mathrm{O}>=\mathrm{E}): 0.0031971$, Fisher's exact test) (Table 1).

Table 2. Antimicrobial resistance prevalence of isolates.

\begin{tabular}{|l|c|c|}
\hline $\begin{array}{l}\text { Antimicrobial } \\
\text { agent }\end{array}$ & $\begin{array}{c}\text { Number of resistant } \\
\text { bacteria }\end{array}$ & $\%$ \\
\hline FUR & 5 & 10.42 \\
\hline AUG & 14 & 29.17 \\
\hline SXT & 15 & 31.25 \\
\hline E & 7 & 14.58 \\
\hline TE & 4 & 8.33 \\
\hline C & 2 & 4.17 \\
\hline CD & 48 & 100.00 \\
\hline ENR & 0 & 0.00 \\
\hline
\end{tabular}

P: Prevalence, FUR: Ceftiofur, AUG: Amoxicillin+Clavulonic acid, SXT: Trimethoprim + Sulfamethoxazole, E: Erythromycin, TE: Tetracycline, C: Chloramphenicol, CD: Clindamycin, ENR: Enrofloxacin

Table 3. Antimicrobial resistance profiles of isolates.

\begin{tabular}{|l|c|c|}
\hline Antimicrobial agent & $\begin{array}{c}\text { Number of } \\
\text { isolates }\end{array}$ & \% \\
\hline $\mathrm{CD}$ & 17 & 35.42 \\
\hline FUR/CD & 1 & 2.08 \\
\hline AUG/CD & 6 & 12.50 \\
\hline $\mathrm{SXT} / \mathrm{CD}$ & 10 & 20.83 \\
\hline TE/CD & 1 & 2.08 \\
\hline FUR/ SXT/CD & 2 & 4.17 \\
\hline AUG/TE/CD & 3 & 6.25 \\
\hline AUG/E/CD & 3 & 6.25 \\
\hline SXT/C/CD & 1 & 2.08 \\
\hline SXT/E/CD & 1 & 2.08 \\
\hline FUR/SXT/E/CD & 1 & 2.08 \\
\hline FUR/AUG /E/CD & 1 & 2.08 \\
\hline AUG/E/C/CD & 1 & 2.08 \\
\hline
\end{tabular}

P: Prevalence, CD: Clindamycin, FUR: Ceftiofur, AUG: Amoxicillin+Clavulonic acid, SXT: Trimethoprim + Sulfamethoxazole, TE: Tetracycline, E: Erythromycin, C: Chloramphenicol. 


\section{Discussion and Conclusion}

P. multocida is defined as a part of the oropharyngeal microbiota of cats, dogs, and other animals. The infections caused by $P$. multocida, which is considered to be zoonotic, are associated with biting, scratching, or licking of the injured tissue. However, infections that occurred in humans without animal contact were also reported $(3,10,12,19,28,29)$. In this study, it was aimed to investigate the isolation of $P$. multocida from intraoral swabs in cats since it is found in the oral microbiota of cats and is a bacterium with zoonotic character. Along with the determination of antibiotic resistance profiles of isolates, it was aimed to update treatment options in case of possible transmission and infection. The prevalence of oral $P$. multocida colonization in cats varies between $10.4 \%$ and $89.9 \%(11,12,13,15,22,25)$. However, it is scientifically misleading to compare these studies without standards on population demographics, sampling sites, sampling methods, transport conditions of samples, analysis methods, and evaluation criteria. In this study, the P. multocida isolation rate was found to be $16 \%$, which was consistent with previous studies.

One of the most important virulence factors of P.multocida which is thought to be commensal is polysaccharide capsule. It was reported that there was a relationship between the capsule types of the agent which they changed geographically, the host and the disease it caused. While serogroups B and E were isolated from bovine hemorrhagic septicemia disease around the world, serogroup E was never isolated in Europe, and serogroup B was isolated only in Eastern Europe. Serogroup F was isolated from cats, ducks, and poultry, type A and D strains were isolated from many domestic and wild animals, and it was reported that human infections were usually caused by serogroup A $(2,6,9)$. While Arumugam et al. (2) reported that all cat and dog isolates in their study were serogroup A, Ferreira et al. (11) reported that $75.6 \%$ of cat isolates were serogroup A. In this study, it was determined that all of $48 \mathrm{P}$. multocida strains were determined as serogroup A, and it was observed that the results were parallel with the limited number of studies conducted on cats.

Few studies on $P$. multocida and oral colonization were usually limited to the determination of capsule serogroups, subspecies, and antibiotic susceptibility. The relationships between the population in which sampling was performed, the physiological, demographic, and behavioral data of this population, and colonization were not investigated. Since the colonization rates of $P$. multocida were not investigated extensively, it was unclear whether the agent was a commensal microorganism of the natural flora in cats or from an external source. In a study carried out by examining 1week-old kittens, it was revealed that the agent was not naturally found in the oral flora, but passed during licking or milking from the mother (10). It was reported that the oral microbiota in cats varied with diet (1). However, in the literature, there is no data indicating the relationship between the presence of oral colonization and age, housing/care conditions, or gender. In this study, the presence of colonization in cats under the age of 1 was found to be significant compared to other age groups. The intestinal microbiota is known to change with age in cats and humans. However, the change of the oral microbiota with age has not yet been fully clarified $(21,26)$. It is considered that long-term cohort studies involving the same animals with larger samples should be carried out to clarify the change on oral microbiota with age, the phenomenon of "microbiota aging." Similarly, in our study, the presence of $P$. multocida was found to be significantly higher in cats with contact the outside compared to cats that not. It was considered that this significant difference was based on behavioral, due to the fact that cats living outside infected each other during hunting, regional and sexual fights, and limited access to food and water resources. However, more extensive cohort studies were considered necessary to prove this assumption.

The infections associated with $P$. multocida are generally attempted to be treated empirically with broadspectrum antibiotics. In previous studies carried out on $P$. multocida isolates originating from cats and dogs, penicillin $(12,22)$, tetracycline $(11,22,34)$, ampicillin $(22,34)$, amoxicillin+clavulanic acid $(11,12)$, ceftiofur $(11,22,34)$, enrofloxacin (34), azithromycin (12), cotrimoxazole (11) antibiotics were reported to be susceptible. The results of this study indicated that enrofloxacin was the most effective antimicrobial agent followed by chloramphenicol, ceftiofur, and tetracycline. These results are consistent with previous studies. Resistance to clindamycin (34), cotrimoxazole $(11,34)$ and erythromycin (34) antibiotics was reported. Clindamycin resistance is known to be common in $P$. multocida strains (34). In this study, resistance to clindamycin was detected in all strains. This result is consistent with previous studies. Tetracycline is one of the recommended agents for use in infections caused by $P$. multocida strains resistant to clindamycin and sulfanamides in humans (34). The evaluation criteria such as break points of many antibiotics for canine or feline $P$. multocida isolates have not been published yet. Nevertheless, in two studies published in recent years, where only MIC values were given, high MIC values for tetracycline were reported in two isolates $(23,24)$. Ujvari et al. (34) stated that tetracycline resistance was not detected in clinical samples in cats, while another surveillance study in the same year reported $4.1 \%$ tetracycline resistance (4).In this study, it was determined 
$4(8.33 \%)$ of the cat isolates were resistant to tetracycline, and $9(18.75 \%)$ of them were moderately susceptible. Tetracycline resistance is routinely reported in P.multocida isolates of pig and bovine origin. In the current study, it was determined that 7 of the isolates were resistant to erythromycin, and 5 of them were moderately susceptible. The result related to erythromycin resistance is consistent with the results obtained previously (11). It was considered that the fact that the studies reporting the result of decreased susceptibility related to erythromycin were associated with $P$. multocida strains isolated from poultry and pet animals could be attributed to the active use of this antibiotic for a long time as a performance enhancer in animals since the 1960s.

In this study, resistance to three and more antibiotic classes was detected in $27 \%$ of the isolates. The MDR patterns detected reveal the developing resistance to some commonly used classes of antibiotics such as lincosamides, cephalosporins, sulphonamides in $P$. multocida isolates. In this study, 13 resistance patterns were detected, and clindamycin and trimethoprim + sulfamethoxazole + clindamycin were observed to be the most common patterns among them. Since resistance/multiple resistance patterns were not reported in previous studies, the results obtained in the current study could not be compared.

Cats are behaviorally in close contact with cohabitants. The results of our study provided data on the prevalence of P.multocida strains colonized in cats, its capsule types, antibiotic resistance and some significant relationships between colonization and population dynamics. In particular, the potential threat related to relatively high rates of MDR P.multocida isolates like any other zoonotic bacteria, should not be underestimated. Horizontal transmission of resistance genes and epidemiological shift observed in susceptible populations lead to an increase in epidemics and MDR bacteria waiting for the right genes to come together. Empirical antibiotic treatments are frequently preferred in animal and human practice, so antibiotic resistance in animal isolates, especially zoonotic bacteria such as $P$. multocida, provides a strong insight of potential resistance in future human infections. It does not appear possible to cease the development of antibiotic resistance with today's technologies. However, selective pressure and spread of resistance can be slowed down by reasonable and responsible antibiotic use and surveillance studies throughout the country.

\section{Acknowledgments}

This work was prepared from the first author's $\mathrm{PhD}$ thesis. The authors would like to thank to Dr. Conny Turni from the University of Queensland and to Prof. Dr. Alper Çiftçi and Assoc. Prof. Dr. Arzu Fındık from Ondokuz
Mayıs University, Faculty of Veterinary Medicine, Department of Microbiology for the positive controls.

\section{Financial Support}

This study was supported by Scientific Research Project Coordination Unit of Istanbul UniversityCerrahpaşa. Project code: TDK-2017-25374.

\section{Ethical Statement}

This study was approved by Istanbul University Animal Experiments Local Ethics Board (23.02.2017).

\section{Conflict of Interest}

The authors declared that there is no conflict of interest.

\section{References}

1. Adler CJ, Malik R, Browne G V, et al (2016): Diet may influence the oral microbiome composition in cats. Microbiome, 4, 23.

2. Arumugam ND, Ajam N, Blackall PJ, et al (2011): Capsular serotyping of Pasteurella multocida from various animal hosts-a comparison of phenotypic and genotypic methods. Trop Biomed, 28, 55-63.

3. Björkholm B, Eilard T (1983): Pasteurella multocida osteomyelitis caused by cat. bite J Infect, 6, 175-177.

4. Bourély C, Cazeau G, Jouy E, et al (2019): Antimicrobial resistance of Pasteurella multocida isolated from diseased food-producing animals and pets. Vet Microbiol, 235, 280284.

5. Boyce JD, Chung JY, Adler B (2000): Pasteurella multocida capsule: Composition, function and genetics. $\mathbf{J}$ Biotechnol, 83, 153-160.

6. Chen Y, Sun E, Song J, et al (2018): Complete Genome Sequence of a Novel T7-Like Bacteriophage from a Pasteurella multocida Capsular Type A Isolate. Curr Microbiol, 75, 574-579.

7. CLSI (2018): Performance standarts for antimicrobial disk and dilution susceptibility tests for bacteria isolated from animals; Informational Supplement. 4th ed. CLSI supplement VET08.

8. Dolieslager SMJ, Riggio MP, Lennon A, et al (2011): Identification of bacteria associated with feline chronic gingivostomatitis using culture-dependent and cultureindependent methods. Vet Microbiol, 148, 93-98.

9. Donnio PY, Lerestif-Gautier AL, Avril JL (2004): Characterization of Pasteurella spp. strains isolated from human infections. J Comp Pathol, 130, 137-142.

10. Fernandez-Esparrach G, Mascaro J, Rota R, et al (1994): Septicemia, peritonitis, and empyema due to Pasteurella multocida in a cirrhotic patient. Clin Infect Dis, 18, 486.

11. Ferreira TS, Moreno LZ, Felizardo MR, et al (2016): Pheno- and genotypic characterization of Pasteurella multocida isolated from cats, dogs and rabbits from Brazil. Comp Immunol Microbiol Infect Dis, 45, 48-52.

12. Freshwater A (2008): Why your housecat's trite little bite could cause you quite a fright: a study of domestic felines 
on the occurrence and antibiotic susceptibility of Pasteurella multocida. Zoonoses Public Heal, 55, 507-513.

13. Ganiere JP, Escande F, Andre G, et al (1993): Characterization of Pasteurella from gingival scrapings of dogs and cats. Comp Immunol Microbiol Infect Dis, 16, 7785.

14. Hatfaludi T, Al-Hasani K, Boyce JDJD, et al (2010): Outer membrane proteins of Pasteurella multocida. Vet Microbiol, 144, 1-17.

15. Ivana S, Câmpeanu G, Bogdan AT, et al (2010): Characterization of Pasteurella sp. strains by macrorestriction profiles of PFGE bands from oral swab samples. Rom Biotechnol Lett, 15, 5034-5041.

16. Kawamoto E, Sawada T, Maruyama T (1997): Evaluation of transport media for Pasteurella multocida isolates from rabbit nasal specimens. J Clin Microbiol, 35, 1948-1951.

17. Kimura R, Hayashi Y, Takeuchi T, et al (2004): Pasteurella multocida septicemia caused by close contact with a domestic cat: Case report and literature review. $\mathrm{J}$ Infect Chemother, 10, 250-252.

18. Knight DP, Paine JE, Speller DC (1983): A selective medium for Pasteurella multocida and its use with animal and human specimens. J Clin Pathol, 36, 591-594.

19. Kouppari G, Garoufi A, Stamos G, et al (1999): Pasturella multocida septicemia and meningitis in an infant. Clin Microbiol Infect, 5, 101-102.

20. Magiorakos A, Srinivasan A, Carey RB, et al (2012): Multidrug-resistant, extensively drug-resistant and pandrug-resistant bacteria: an international expert proposal for interim standard definitions for acquired resistance. Clin Microbiol Infect, 18, 268-281.

21. Masuoka H, Shimada K, Kiyosue-Yasuda T, et al (2017): Transition of the intestinal microbiota of cats with age. PLoS One, 12, 1-9.

22. Mohan K, Kelly PJ, Hill FWG, et al (1997): Phenotype and serotype of Pasteurella multocida isolates from diseases of dogs and cats in Zimbabwe. Comp Immunol Microbiol Infect Dis, 20, 29-34.

23. Morrissey I, Moyaert H, de Jong A, et al (2016): Antimicrobial susceptibility monitoring of bacterial pathogens isolated from respiratory tract infections in dogs and cats across Europe: ComPath results. Vet Microbiol, 191, 44-51.
24. Moyaert H, de Jong A, Simjee S, et al (2019): Survey of antimicrobial susceptibility of bacterial pathogens isolated from dogs and cats with respiratory tract infections in Europe: ComPath results. J Appl Microbiol, 127, 29-46.

25. Moyaert H, de Jong A, Simjee S, et al (2014): Antimicrobial resistance monitoring projects for zoonotic and indicator bacteria of animal origin: common aspects and differences between EASSA and EFSA. Vet Microbiol, 171, 279-283.

26. Nakanishi H, Furuya M, Soma T, et al (2019): Prevalence of microorganisms associated with feline gingivostomatitis. J Feline Med Surg, 21, 103-108.

27. NCCLS (2004): Performance Standarts for Antimicrobial Disk and Dilution Susceptibility Tests for Bacteria Isolated from Animals; Informational Supplement. NCCLS document M31-S1.

28. Orsini J, Perez R, Llosa A, et al (2013): Non-zoonotic Pasteurella multocida infection as a cause of septic shock in a patient with liver cirrhosis: a case report and review of the literature. J Glob Infect Dis, 5, 176.

29. Tamaskar I, Ravakhah K (2004): Spontaneous bacterial peritonitis with Pasteurella multocida in cirrhosis: case report and review of literature. South Med J, 97, 11131115.

30. Tefera G, Smola J (2002): Modification of Cary-Blair Transport Medium for Pasteurella multocida and Mannheimia haemolytica. Acta Vet Brno, 71, 229-233.

31. The European Committee on Antimicrobial Susceptibility Testing. (2017): Breakpoint tables for interpretation of MICs and zone diameters. Version 7.0. http://www.eucast.org. (Accessed March 12,2020).

32. Townsend KM, Boyce JD, Chung JY, et al. (2001): Genetic organization of Pasteurella multocida cap loci and development of a multiplex capsular PCR typing system. $\mathrm{J}$ Clin Microbiol, 39, 924-929.

33. Townsend KM, Frost AJ, Lee CW, et al. (1998): Development of PCR assays for species-and type-specific identification of Pasteurella multocidaisolates. J Clin Microbiol, 36, 1096-1100.

34. Ujvári B, Weiczner R, Deim Z, et al. (2019): Characterization of Pasteurella multocida strains isolated from human infections. Comp Immunol Microbiol Infect Dis, 63, 37-43. 